DOI: 10.32844/2222-5374-2020-104-2.06

УДК: 343.9

\author{
Кротюк А. М., \\ доцент кафедри кримінології та кримінально-виконавчого права \\ Національної академії внутрішніх справ, \\ кандидат юридичних наук
}

\title{
СПЕЦІАЛЬНО-КРИМІНОЛОГІЧНІ ЗАХОДИ ЗАПОБІГАННЯ ЗЛОЧИНАМ У СФЕРІ НЕЗАКОННОГО ОБІГУ НАРКОТИЧНИХ ЗАСОБІВ, ПСИХОТРОПНИХ РЕЧОВИН, ЇХ АНАЛОГІВ І ПРЕКУРСОРІВ У ВЕЛИКОМУ МІСТІ
}

Актуальність статті полягає в тому, шо в Україні серед багатьох проблем, що стоять перед суспільством і державою, на одне з перших місць виходить проблема протидї злочинності в цілому. Крадіжки, пограбування, розбої, шахрайство, торгівля наркотиками та інші кримінально каранні дії завжди бентежили спокій законослухняних громадян. Особливого резонансу в умовах сьогодення набуває саме проблема протидії наркозлочинності. Тому запобігання незаконному обігу наркотиків була і залишається актуальною і на сьогодні, у зв'язку з набуттям міжнародного та транснаціонального характеру і тому не є притаманною якійсь одній конкретній країні, а охопили практично весь світовий простір. Метою статті є визначення основних напрямів спеціально-кримінологічних заходів запобігання злочинам у сфері незаконного обігу наркотичних засобів, психотропних речовин, їх аналогів і прекурсорів у великому місті та розробка системи таких заходів. Проблема запобігання злочинів у сфері незаконного обігу наркотичних засобів, психотропних речовин, їх аналогів і прекурсорів у великому місті повинна вирішуватися в руслі протидії зі злочинністю взагалі. Обов'язковою передумовою успіху в реалізації загальносоціальних заходів запобігання злочинам у сфері незаконного обігу наркотичних засобів. психотропних речовин, їх аналогів і прекурсорів, зокрема і всієї злочинності взагалі, $\epsilon$ досягнення якісно іншого стану нашого суспільства, в якому людина повинна мати міцний життєвий статус. Для цього необхідно зробити істотні перетворення у найважливіших сферах суспільного життя з урахуванням при цьому інтересів усіх верств суспільства. Для попередження злочинів у сфері незаконного обігу наркотичних засобів. психотропних речовин, їх аналогів і прекурсорів необхідно реалізувати комплекс соціально-економічних, політичних, організаційно-управлінських, виховних, технічних, правових та інших заходів. У статті проаналізовано поняття, сутність, суб'єкти, механізм спеціально-кримінологічні заходів запобігання корисливим насильницьким злочинам, що вчиняються етнічними організованими злочинними групами, які полягають у комплексному поєднанні всіх різновидів та рівнів запобіжного впливу.

Ключові слова: запобігання, спеціально-кримінологічні заходи, організовані злочинні групи, наркотичні засоби, велике місті. 
Актуальність теми. В Україні серед багатьох проблем, що стоять перед суспільством і державою, на одне з перших місць виходить проблема протидії злочинності в цілому. Крадіжки, пограбування, розбої, шахрайство, торгівля наркотиками та інші кримінально каранні дії завжди бентежили спокій законослухняних громадян [1]. Особливого резонансу в умовах сьогодення набуває саме проблема протидії наркозлочинності. Тому запобігання незаконному обігу наркотиків була і залишається актуальною і на сьогодні, у зв'язку з набуттям міжнародного та транснаціонального характеру і тому не $є$ притаманною якійсь одній конкретній країні, а охопили практично весь світовий простір.

Враховуючи вище викладене, на сьогодні актуальне питання спеціально-кримінологічних заходів запобігання корисливим насильницьким злочинам, що вчиняються етнічними організованими злочинними групами.

Стан дослідження. Проблема запобігання злочинам у сфері незаконного обігу наркотичних засобів, психотропних речовин, їх аналогів і прекурсорів у великому містіє однією з найголовніших у кримінології. Своє бачення про спеціально-кримінологічні заходи запобігання злочинам у сфері незаконного обігу наркотичних засобів, психотропних речовин, їх аналогів і прекурсорів у великому місті висловлювали багато вітчизняних та зарубіжних кримінологів, а саме: О.М. Бандурка, В.В. Василевич, М.Ю. Валуйська, О.Ф. Гіда, Б.М. Головкін, В.В. Голіна, І.М. Даньшин, О.М. Джужа, А.І. Долгова, В.І. Дьордяй, Ю.Ф. Іванов. В.М. Кудрявцева, С.О. Павленко, В.Г. Севрук, Г.В. Шевченко

Метою статті $\epsilon$ визначення основних напрямів спеціально-кримінологічних заходів запобігання злочинам у сфері незаконного обігу наркотичних засобів, психотропних речовин, їх аналогів і прекурсорів у великому місті та розробка системи таких заходів.

Виклад основного матеріалу. Заходи спеціально-кримінологічного запобігання злочинам у сфері незаконного обігу наркотичних засобів. психотропних речовин, їх аналогів і прекурсорів у великому місті здійснюється спеціально уповноваженими на це органами та установами, на які законом безпосередньо покладено боротьбу зі злочинністю серед окремих верст населення, соціальних груп. На відміну від загальносоціальної профілактики спеціальна має на меті вказати членам суспільства на неможливість злочинного варіанта поведінки і створює такі умови, щоб захистити всіх членів суспільства від протиправних дій окремих його представників з допомогою покладання на винних осіб обов'язку понести передбачене законом покарання [2].

B.В. Голіна розглядає спеціально-кримінологічне запобігання злочинам як сукупність самостійних, але внутрішньо пов'язаних між собою і доповнюючих один одного напрямів боротьби зі злочинністю, змістом яких є діяльність державних органів, громадських організацій і громадян у розробці та реалізації заходів, спрямованих на запобігання, виникнення, обмеження, усунення криміногенних явищ і процесів, які створюють злочинну детермінацію, а також недопущення вчинення злочинів на різних стадіях злочинної поведінки. Він характеризує суб'єкти спеціальнокримінологічного запобігання злочинам в якості різних варіантів: законодавчі, виконавчо-розпорядчі, державні координуючі, правоохоронні 
та правозастосовчі органи, органи державного, культурно-виховного і господарського управління, навчальні, медичні, релігійні й інші органи, організації та установи, воєнізовані формування, громадські організації, рухи, фонди, соціальні групи, об'єднання громадян, батьків, родичі, сусідів, громадян [3, с. 12-25].

Так вчені А.І. Долгова, В.М. Бурлаков, А.Ф. Зелінський під спеціальним запобіганням злочинності розуміють систему впливу на процеси детермінації та причинності злочинності, які стосуються окремих соціальних груп, сфер діяльності та об'єктів, які характеризуються підвищеною ймовірністю вчинення злочинів [4, с. 445, 451].

А. Е. Жалинський, розглядаючи структуру спеціально-кримінологічного попередження, пропонує виокремити такі елементи: мету, прийоми та навички, організаційні форми заходів, умови, попереджувальний ефект. На його думку, спеціальні заходи попередження злочинів можна поділити на три групи, залежно від механізму впливу на криміногенні чинники:

- заходи-норми, тобто спеціальні норми правил поведінки, що полегшують виконання кримінального закону та перешкоджають вчиненню злочину;

- заходи-команди (сигнали), тобто спонуки до проведення профілактичної роб оти (подання, окремі ухвали, узагальнення судової практики, накази, що не носять нормативного характеру);

- заходи-дії, які полягають у безпосередньому впливі на криміногенні фактори та в реальній зміні несприятливої ситуації. Заходи-дії, у свою чергу, поділяються на такі види: заходи контрольно-наглядового характеру, спрямовані на підтримання існуючих режимів, процесів і станів, на захист їх від різного роду порушень; заходи регулювання ситуацій, що вже склалися, виправлення несприятливої обстановки, що може призвести до злочину [5, с. 158-161].

Серед кримінологів до розуміння спеціально-кримінологічного (або спеціального запобігання злочинності) не має єдиного підходу. Не зупиняючись детально на розгляді цього питання, підтримаємо позицію тих фахівців, які визначають таке запобігання як «сукупність заходів боротьби зі злочинністю, змістом яких є різноманітна робота державних органів, громадських організацій, соціальних груп і громадян, спрямована на усунення причин та умов, що породжують і сприяють злочинності, а також недопущення вчинення злочинів на різних стадіях злочинної поведінки» [6, c. 55].

Отже, на думку професора О.М. Джужі - «на рівні спеціальної профілактики мета боротьби зі злочинністю, певними ії̈ видами й конкретними злочинами визначена як єдина чи головна для відповідних заходів соціального контролю, соціальної реабілітації та правоохоронної діяльності. Розробка й реалізація заходів спеціальної профілактики прямо зумовлена наявністю злочинності, її рівнем ї характером, впливом криміногенних детермінант» [7, с. 169].

Заходи спеціально-кримінологічного запобігання повинні органічно доповнювати заходи загальносоціального запобігання. Для їх реалізації держава має виділяти певні фінансові ресурси. Ці заходи повинні виконуватися не тільки підрозділами ОВС, але й іншими державними, недержав- 
ними органами і інститутами із залученням громадськості. Зміст попереджувальної діяльності злочинів у сфері незаконного обігу наркотичних засобів, психотропних речовин, їх аналогів і прекурсорів у великому місті зумовлюється декількома критеріями, а саме: часовим етапом або стадією розвитку злочинної діяльності і навіть до початку її здійснення; людським чинником - особистістю винного; зовнішніми об'єктивними обставинами; методами, що застосовуються на даному етапі роботи, і суб'єктами, що беруть участь в реалізації арсеналу превентивних заходів.

Кримінологічна профілактика посідає домінуюче місце в системі спеціально-кримінологічного попередження злочинності. Даний напрямок роботи із своєчасного попередження виникнення і обмеження поширення криміногенних чинників, які вже детермінують або надалі будуть зумовлювати злочинність у сфері незаконного наркообігу, відіграє велику роль. На практиці профілактичних заходів уживають тоді, коли спосіб життя особи, її погляди, установки, звички або ж оточення, в якому вона перебуває, свідчать про те, що для неї не виключений у майбутньому злочинний спосіб поведінки, іншими словами, у особи є схильність до вчинення злочину. При цьому необхідно зауважити, що профілактика дозлочинної поведінки осіб, що вчинили злочини у сфері незаконного обігу наркотичних засобів, психотропних речовин, їх аналогів і прекурсорів за своїм змістом багато в чому збігається з аналогічними напрямами роботи з попередження інших видів злочинів. Крім того, профілактика злочинів у сфері незаконного наркообігу повинна бути спрямована не лише на корекцію поведінки, способу життя, морально-психологічних характеристик потенційних злочинців даного виду злочинів, їх оточення.

Серед спеціально-кримінологічні заходи запобігання злочинам у сфері незаконного обігу наркотичних засобів, психотропних речовин, їх аналогів і прекурсорів у великому місті особливо слід виділити заходи інформаційно-виховного, соціально-психологічного, лікувально-профілактичного, соціально-адаптаційного, організаційно-управлінського і правового характеру.

Так, під час опитування респондентів, було встановлено, що найбільш доцільними спеціально-кримінологічними заходами запобігання злочинам у сфері незаконного обігу наркотичних засобів, психотропних речовин, їх аналогів і прекурсорів у великому місті є: заходи інформаційно-виховного - $67 \%$, соціально-психологічного - 57 \%, лікувально-профілактичного -73\%, соціально-адаптаційного - $63 \%$,, організаційно-управлінського 55 \%, і правового характеру - 62 \%. Зупинимося на найважливіших, з нашої точки зору, профілактичних заходах.

Основними ознаками спеціально-кримінологічних заходів запобігання є: 1) вони направлені саме на запобігання злочинності, її окремих видів та конкретних злочинів (у даному випадку злочинів проти моральності); 2) арсенал засобів спеціально-кримінологічного запобігання характеризуються взаємодією загальноуправлінських і загальновиховних, соціальних і правових заходів, що розраховані впливати саме на злочинність, її окремі види або недопущення конкретних злочинів; 3) суб'єктами спеціально-кримінологічного запобігання виступають організаційні структури, 
для яких боротьба зі злочинністю складає основну (одну з основних) функцію або хоча б виділена в переліку функцій [8, с. 296].

Система суб'єктів спеціально-кримінологічних заходів запобігання корисливим насильницьким злочинам, що вчиняються етнічними організованими злочинними групами будується відповідно до рівня та об'єкту впливу.

У першу їх групу входять органи державної влади та органи місцевого самоврядування. Вони визначають основні напрями, завдання, функції запобіжної та профілактичної діяльності, забезпечують фінансування і реалізацію регіональних та місцевих програм, спрямованих на запобігання, профілактику та припинення злочинів [9].

Другу групу складають правоохоронні органи всіх рівнів. Особливе місце серед вказаних суб'єктів займають органи внутрішніх справ, оскільки боротьба зі злочинністю та запобігання злочинам $€$ їх прямим обов'язком [9].

Третю утворюють організації, підприємства та установи з різними формами власності, громадські організації, асоціації та фонди [9].

Окремої уваги вимагає робота з неповнолітніми, які дуже часто стають потерпілими від незаконного наркообігу внаслідок своєї безтурботності, необачності, зайвої довірливості, а також бажання самоствердитися в компанії своїх однолітків. Батьки або особи, які їх заміняють, повинні піклуватися про безпеку своїх дітей: пояснювати і постійно нагадувати дитині, щоб вона під жодним приводом не піддавалися умовлянням спробувати наркотики; придивлятися до друзів і знайомих своєї дитини, особливо до старших за віком. Так, Ч. Беккарія, відзначав, що виховання - найбільш важливий, але й важкий засіб попередження злочинності [10, с. 106].

Нині пріоритетними напрямами спеціально-кримінологічого запобігання корисливим насильницьким злочинам, що вчиняються етнічними організованими злочинними групами для України є: профілактика наркоманії за участі всіх зацікавлених органів державної влади, місцевого самоврядування й громадських організацій; удосконалення законодавчого регулювання та нормативної бази антинаркотичної діяльності; розроблення наукового підгрунтя й упровадження новітніх технологій у сфері протидії наркоманії та наркобізнесу; ефективне використання можливостей міжнародного співробітництва. Міжнародний аспект заходів протидії транснаціональному наркобізнесу, яким займаються особи циганської національності, полягає в різноманітних правотворчих, правозастосовних та інших заходах боротьби з цим явищем, які розробляють і здійснюють на міжнародному рівні [11].

Підсумовуючи зазначене, слід відзначити, що спеціально-кримінологічне запобігання злочинам у сфері незаконного обігу наркотичних засобів, психотропних речовин, їх аналогів і прекурсорів у великому місті широкий комплекс різноманітних за характером заходів, безпосередньо спрямованих на ліквідацію протиправної поведінки осіб, які вчиняють злочини у сфері незаконного обігу наркотичних засобів, психотропних речовин, їх аналогів і прекурсорів Об'єктами профілактичного впливу є криміногенні вчинки, що детермінують формування особи злочинців, ситуації, які зумовлюють правопорушення, полегшують їх вчинення. Таке запобігання 
здійснюється на різних рівнях (у межах усієї країни, міста, району, населеного пункту) широким колом суб'єктів профілактичної діяльності.

Висновки. Підводячи підсумок, слід зауважити, що реалізація вище перерахованих профілактичних заходів сприятиме забезпеченню громадського порядку в місцях скупчення молоді, вживання наркотичних засобів, запобігання пияцтва та інших негативних чинників, які ведуть антигромадський паразитичний спосіб життя, i, відповідно, будуть опосередковано сприяти попередженню злочинності [12, с. 159]. Тому нині пріоритетними напрямами запобігання злочинам у сфері незаконного обігу наркотичних засобів, психотропних речовин, їх аналогів і прекурсорів у великому місті для України є: профілактика такої злочинності за участі всіх зацікавлених органів державної влади, місцевого самоврядування й громадських організацій; удосконалення законодавчого регулювання та нормативної бази; розроблення наукового підгрунтя й упровадження новітніх технологій у сфері запобігання корисливим насильницьким злочинам, що вчиняють етнічні організовані злочинні групи; ефективне використання можливостей міжнародного співробітництва [11].

\section{СПИСОК ВИКОРИСТАНИХ ДЖЕРЕЛ}

1. Севрук В. Г. Заходи протидії неповнолітнім особам циганської національності, які вчиняють злочини. Сучасні проблеми правового, економічного та соціального розвитку держави: матеріали наук.-практ. конф. (Харків, 19 квіт. 2012р.). Х.: ХНУВС, 2012. С. 300-302.

2. Бандурка О. М. Протидія злочинності та профілактика злочинів : моногр. / Бандурка О. М. Х.: Харків. ун-т внутр. справ, 2011. 308 с.

3. Голина В. В. Специально-криминологическое предупреждение преступлений (теория и практика) : дис. ... доктора юрид. наук : 12.00.08. X., 1994. 569 c.

4. Криминология: учеб. для вузов / под. ред. д.ю.н., проф. А.И. Долговой. [2-е изд.]. М.: Изд-во НОРМА, 2002. 848 с.

5. Жалинский А. Э. Специальное предупреждение преступлений в СССР / Жалинский А. Э. - Львов : Вища шк., 1976. 193 с.

6. Кримінологія: Загальна та Особлива частини: підручник / I.М. Даньшин, В.В. Голіна, М.Ю. Валуйська та ін.; за заг. ред. В.В. Голіни. 2-ге вид. перероб. і доп. Х.: Право, 2009. 288 с.

7. Кримінологія: навч. посіб. / Ю.Ф. Іванов, О.М. Джужа. К.: Вид. ПАЛИВОДА А.В., 2006. 264 с.

8. Криминология: учебник / под ред. В.М. Кудрявцева и В.Е. Эминова. - 4-е изд., перераб. и доп. М.: Норма, 2010. 800 с.

9. Кримінологія: питання та відповіді. URL: https://pidruchniki. com/81540/pravo/kriminologiya.

10. Беккария Ч. О преступлениях и наказаниях: Пер. с итал. М.: Стелс, 1995. 304 c.

11. Севрук В.Г., Павленко О.С. Заходи протидії транснаціональному наркобізнесу, що вчиняється представниками окремих етнічних груп. Юридичний часопис Нац. акад. внутр. справ України. 2015. № 2(10). С. 193-205.

12. Дьордяй В. І. Кримінологічна характеристика та запобігання органами внутрішніх справ згвалтувань, що вчиняються неповнолітніми 
[Текст]: дис. ... канд. юрид. наук: 12.00.08; Нац. акад. внутр. справ. Київ, 2015. 233 c.

\section{A. Krotiuk}

\section{SPECIAL CRIMINOLOGICAL MEASURES FOR CRIME PREVENTION IN THE FIELD OF ILLEGAL TRAFFICKING OF DRUGS, PSYCHOTROPIC SUBSTANCES, THEIR ANALOGUES AND PRECURSORS IN A BIG CITY}

The relevance of the article is that in Ukraine, among the many problems facing society and the state, one of the first places is the problem of combating crime in general. Thefts, robberies, robberies, fraud, drug trafficking and other criminal acts have always disturbed the peace of law-abiding citizens. The problem of combating drug crime is gaining special resonance in today's conditions. Therefore, the prevention of drug trafficking was and remains relevant today, due to the acquisition of international and transnational character and therefore is not specific to any one country, but covered almost the entire world. The purpose of the article is to determine the main directions of special criminological measures to prevent crimes in the field of illicit trafficking in narcotic drugs, psychotropic substances, their analogues and precursors in a large city and to develop a system of such measures. The problem of crime prevention in the field of illicit trafficking in narcotic drugs, psychotropic substances, their analogues and precursors in the big city must be addressed in the context of combating crime in general. A prerequisite for success in the implementation of general social measures to prevent crimes in the field of drug trafficking. psychotropic substances, their analogues and precursors, in particular and all crime in general, is to achieve a qualitatively different state of our society, in which a person must have a strong life status. To do this, it is necessary to make significant changes in the most important spheres of public life, taking into account the interests of all segments of society. To prevent crimes in the field of drug trafficking. psychotropic substances, their analogues and precursors must implement a set of socio-economic, political, organizational and managerial, educational, technical, legal and other measures. The article analyzes the concept, essence, subjects, mechanism of special criminological measures to prevent mercenary violent crimes committed by ethnically organized criminal groups, which consist in a complex combination of all types and levels of preventive influence.

Keywords: prevention, special criminological measures, organized criminal groups, drugs, big city. 